\title{
An Alternative Approach in Constructivist Mentoring for Textual Analysis in Turkish Courses
}

\author{
Dilek ÜNVEREN $^{1} \&$ Gülreyhan KARAKUŞ ${ }^{2}$ \\ ${ }^{1}$ Faculty of Education, Department of Turkish and Social Studies, Süleyman Demirel University, Isparta, Turkey \\ ${ }^{2}$ Bsc Faculty of Business Administration, Bilkent University, Ankara, Turkey \\ Correspondence: Dilek ÜNVEREN, Faculty of Education, Süleyman Demirel University, Isparta, Turkey. E-mail: \\ dilekkapanadze@sdu.edu.tr
}

Received: September 10, 2019

Accepted: November 20, 2019

Online Published: January 29, 2020

doi:10.5539/ies.v13n2p71

URL: https://doi.org/10.5539/ies.v13n2p71

\begin{abstract}
This article grounds on Jean Piaget's cognitive development theory, particularly aiming to provide a leading approach in Turkish language classes by focusing on children's learning process. In Turkey, Piaget's theory is applied in Turkish language curricula since 2005. Language classes play a fundamental role in improving cognitive skills positively, affecting the overall success of students in cognitive ability evaluation tests. This article is based upon Piaget's cognitive development theory being an effective learning system for improving critical thinking and personal development skills. It proposes a realist approach to systemize textual analysis in language classes in order to increase academic success, as well as leaving space for individuality and creativity for learners by enhancing the power of analytical thinking and using interdisciplinary links to enhance knowledge. In light of this aim, the article analyses four rudiment text pillars - 'time, plot, setting, and character' to provide a systematic representation for the connection and interaction between these pillars in order to build an alternative constructivist method for language classes.
\end{abstract}

Keywords: constructivism, language teaching, textual analysis

\section{Introduction}

\subsection{Problem Analysis}

Learning a language is an active process that lets people connect with the world around them; and link up abstracts and concretes. Learning a language is a process done cerebrally, while it is also proven to improve other cognitive activities including critical thinking skills plus enhance learning in other subjects (Güneş, 2011; cited in Salman \& Aydın, 2018). Until 2005, Turkish Language Courses Curriculum followed passive learning objectives with teacher-centred classes, and the educational focus was on quantitative and systematic teaching methods, where subjects were taught to everyone the same way and at equal levels. New Turkish Curriculum published in 2005 had a new goal of enabling students to grasp the views of language in different contexts, allowing students to express themselves; and to enrich the world of emotion, thought and imagination by reaching different sources of information (Salman \& Aydin, 2018). For any of these qualifications to become a useful outcome for further development, it requires subordinate thinking skills to be improved, especially critical thinking skills. Hypothetically, the structure-wise requirements are well established to provide an effective learning environment for children in language classes; however, the evaluation show dramatic results of failure, and a big gap between reality and expectations. Firstly, an analysis of previous works will provide possible reasons for this gap and a wider view to observe the missing link between the theoretical and practical results of the new system. Secondly, an alternative approach to the theoretical work will conduce to better results by reducing possible misinterpretations. The problem will be solved by analysing previous researches, and establishing an alternative proposal in order to support and develop the methods used in language classes to achieve the desired qualifications and outcomes mentioned in the new Turkish language curricula.

\subsection{Further Focus}

There are several international exams evaluating the cognitive development skills of children in school courses including language courses. PISA Reports in 2015 reported Turkey as the $3^{\text {rd }}$ least successful country in cognitive-based exams, and that language was the worst performing by students (Ünveren, 2016). This result has 
leaded us to focus on the reasons and curriculum objectives in order to find new solutions and create a more effective and sustainable language teaching system. The same curriculum objectives used since 2005 for language teaching are used in several leading educational systems as a world trend now, and Ünveren's (2016) experiment has shown that children in Turkish language classes are capable of learning, but are not aware of how to learn or personalize the provided information to create a subordinate knowledge structure. If it is not the hypothetical system, or the cognitive abilities, then the problem is acquired to be a missing link between the right system and the capable children, which would provide solutions for the 'how to learn' obscurity in the end.

\subsection{Literature Review}

Since the late $20^{\text {th }}$ century, Jean Piaget's 'Cognitive Development Theory on Children' was considered to be one of the leading concepts for improving children's cognitive development skills, uniquely focusing on reasons behind that trigger to improve cognitive ability. Piaget sees the way to adapt knowledge as one's ability to survive in an environment by using that knowledge in a 'viable' way (von Glasersfeld, 1998, as cited in Prouix, 2006, p. 5, cited in Kretchmar, 2019). Hence, the knowledge will be acquired by the individual only if it is 'viable', meaning that the individual can relate and connect it to their own life, which in a language class, can be provided by appropriate textual analysis methods for analysing texts. Textual analysis is a qualitative method to discover meaning from documented expressions by focusing on the underlying ideological and cultural assumptions of a text (Fürsich, 2018). It is also the chosen method for language teaching in Turkish language teaching curricula (MEB, 2019). In contrast to systematic quantitative content analysis- which was the method to be used until 2005 in Turkish curriculum- it is a combination of various analysis approaches and techniques with an unlimited number of interpretations to reach an infinite numbers of inferences. There are several approaches to be used in textual analysis that directly denotes the researcher's disposition towards the text, and therefore, constitutes the judgement point of the analysis. As McKee (2003, p. 15) explains it, "We can never know for certain how people interpreted a particular text but we can look at the clues, gather evidence about similar sense-making practices, and make educated guesses." The most common approach in textual analysis is the post-structuralist approach, where the cognitive skills are used within an open- minded thinking environment by connecting relevant information in certain combinations to create knowledge. As fancy as it sounds, making interpretations or generating ideas from a given concept requires a wide range of ground knowledge as well as critical and abstract thinking skills to be a relatively sophisticated level. On the other hand, the researches show that most of the abilities that is associated with abstract thinking are a function of the frontal lobe in the brain, and this area cannot function in full potential until the early 20's (Loftin, 2018), which emphasizes that it is quite unrealistic to expect children to improve their cognitive skills to the desired levels only by their own effort, while abstract thinking abilities are already not fully accomplished to 'analyse' a text fully like an adult would do. As Loftin (2018) exemplifies, a young child would learn to call a stuffed animal a dog, and would attach more information to that concept by adding relevant objects, and provides 'thinking' as a result of her classification of objects and experiences. The abstract thinking is the product of the combination and classification of these objects and experiences in mind that is needed in critical thinking and knowledge creation process.

\subsection{Hypotheses, Aim and Method of the Research}

The 'mentoring system', as part of the cognitive teaching curricula is expected to lead the instructors towards the ideas to be given in the texts by providing a ground knowledge in a certain framework, while expecting the students to relate this framework into their own logical reasoning out processes. Between the structural and realist approaches as alternatives to post- structural approach, the realist approach is considered to be a more straightforward and experience-based way of analysing texts, which may create less abstract and more systematized ways to analyse texts; hence, may be more suitable for the early childhood mentoring. The article provides an alternative realist mentoring framework formula revealing the co- dependency between rudiment text pillars as 'time, plot, setting, and character'. It indicates the reasons to look at each pillar clearly, and to show an alternative path to follow for the learners.

This study is developed in accordance with a qualitative approach. Out of qualitative approaches, generic/basic qualitative research design is adopted while developing the formula for textual analysis. Qualitative research has evolved a lot recently by developing three major methodologies defined as phenomenology, ethnography, and grounded theory (Holloway \& Todres, 2003; Johnson, Long, \& White, 2001; Morse, 1989; Richards \& Morse, 2007; Smith, Becker, \& Cheater, 2011). However, the need for more flexible methodologies has also increased (Holloway \& Todres, 2003), since frequently used and accepted methodologies have some limitations to explain some studies, meet their aims and answer their research questions, so they do not fit into them (Caelli, Ray, \& Mill, 2003). Therefore, new methodologies as discourse analysis, life history, and narrative inquiry have been started to be accepted among qualitative approaches. Generic/Basic qualitative research is the one that is considered under 
that broad category; with its types of interpretative and descriptive basic qualitative research (Caelli et al., 2003). This is the most common qualitative study found in educational studies (Merriam, 2009). Generic approach gives opportunities for researchers go around and beyond the boundaries of established methodologies. Generic approach employs the instruments of traditional methodologies, and develops research models that can fit into their discipline, aim and research questions (Kahlke, 2014). Merriam (2009) defines the purpose of basic qualitative research in educational studies as to improve educational practices and processes, and to understanding and explaining them in-depth. Descriptive account of the findings is presented and discussed by referring to the literature that frames the study. So, a study in basic qualitative design can be done to understand, explore or offer strategies, techniques, and practices that is/can be used in effective educational practices (Worthington, 2010). As described as basic/generic qualitative study, this is a specific research on textual analysis in language lessons that "seek to discover and understand a phenomenon, a process, or the perspectives" (Merriam, 1998, p.11). Data will be collected through examples from literary works and discussion will be based on the documents, in other words, literary texts and on the frame of the study, that 'constructivist educational approach'. The findings of this research will be a combination of description and developing a formula to be used in language lessons during textual analysis based on theoretical frame of constructivist educational approach.

In the light of generic/basic qualitative research design, analysing the 4 text pillars in detail with the functions they establish on the base of the rational cloze will lead to reach a standard 'base' for any given pillar to clarify the reasons behind the details that supplement the main idea in these texts. The idea is given by the simplest form of formulation reflecting the interaction between the pillars, and the result of the formula is given as the aim of reaching ' $\mathrm{m}$ ', representing the main idea to be gained from the text. The pillars are represented consecutively: ' $\mathrm{t}$ ' as time; 'p' as plot; 's' as setting; and 'c' as character. The functions of these pillars will be analysed by induction, and interdisciplinary approaches will come to a conclusion with relevant examples from different literature sources, as well as academic references.

\section{Four Pillars of the Alternative Formula for Textual Analysis}

Textual analysis is a methodology, and the formulation that will be explained below improves its scientific connotation to create a standardized recipe for any children to follow in the early stages of textual interpretations. Here, the formula strongly focuses on the fixed elements of a textual analysis, and is flexible enough to be reshaped by each mentor's choices of texts and the ways to analyse them.

\subsection{Time}

The first element of the described formula is 'time', and constructivist teaching would require the first time focus to be on the rational reasons of time references, as well as the genre effects implied instinctively by the authors. 'Once upon a time', without any further information about the text, represents a story with a timeless message. This does not necessarily imply that the main idea given is a universal concept; it rather identifies the idea was considered timeless for the time zone it was written. This structure is usually observed on fairy tales or stories told to children to provide life- time messages, as well as emphasizing certain virtues. The timeless literature texts are mostly created before the industrial revolution by no coincidence. As for many other analytical discourses related to social studies, literary analysis also gains a different approach to observe realities 'before' and 'after' industrial revolution, under the names of 'eschatology' and 'history': Historic works focus on the future being an unpredictable, or a being repeating process of time. The visible social change in eschatological beliefs into more history oriented ones begins of time changing with societies going through irreversible changes. The massive shift of virtues in societies has led to questioning the unquestioned solid virtues. As a result, 'time' has gained more importance; because now, it has become a 'variable' in criticizing truths (Landmesser, 2015).

The future perceived to bring uncertainty, as well as the past not being the same as present is a modern concept, and now societies require certain time periods to be classified in genres in order to analyse the reason behind these time references. A period of time emphasized in one genre might refer to a totally different meaning in another one. Modern literature texts use time very precisely; In 'Villette' by Charlotte Bronte, time is used with periodically repeating actions: "Mr. Home stayed two days." (Bronte, 1993, p. 14) was given in the beginning of chapter 11 as the starter of the plot, while time settings such as "I was up the next morning an hour before daybreak, and finished my guard, kneeling on the dormitory floor beside the centre stand, for the benefit of such expiring glimmer as the night lamp afforded in its last watch." (p. 314) were used frequently to represent preciseness in daily life. Similarly, in Fyodor Dostoyevsky's 'Idiot', chapter 4 begins as "It has been one week that the two characters of our story had met in the green bank. It was a clean day, half past ten in the morning, Varvara Ardalynova was returning to Ptitsyn" (Dostoyevksy, 2012, p. 583) representing time as a fundamental concept in daily life. For post-modern writings, the time periods no more represent themselves in an equal value, but time is rather emphasized based on 
specific days that events described as the climax occurs. In 'Chronicle of a Death Foretold' by Gabriel Garcia Marquez, the very first sentence of the book is the climax itself: "ON THE DAY they were going to kill him, Santiago Nasar got up at five- thirty in the morning to wait for the boat the bishop was coming on" (Marquez, 2003, p. 1). The day that the climax of the story is not given as one of the days: with an extraordinary event; it is rather that day, the whole novel is about, and the time is only important if it is directly serving to the climax point of the story. Hence, the time becomes more dependent on the plot, and postmodernism shows its reflux against the modern literature's emphasis on 'time' itself, and uses it only when it can empower the focus on the main idea.

The difference between the pre- modern, modern, and post-modern texts in terms of time structures lies on the understanding of time. What is called history today is an open-ended and unpredictable progress to go through, whereas for eschatological discourses of pre-modern eras, the time is perceived as a droning system. Therefore, 'once upon a time' does not require an exact date to emphasize its main idea, whereas for a modern text, the time can create a fundamental difference in character's lives as it is seen to have a direct impact on daily life. Going further on systematization, time as a pillar is now analysed to have an independent power that itself can represent a message given in a literary piece. Therefore, the independent value that 'adds' to the value of the main idea is shown as ' $t+$ '.

\subsection{Plot}

Plot may be explained as the path of a text from the beginning to the end, which carries the textual elements towards the main idea. Moreover, plot may be the 'being' or the 'action' part of the story. Ernest Hemingway's short story 'For Sale: Baby shoes, never worn' (Flora, 1989) exemplifies a plot with no characters, time or setting; yet carrying an idea inside.

Questioning 'why' the plot is used in a text is shortly because the text needs an order to follow; for the elements to be shaped accordingly to create a flow and it limits other textual elements to be used in a certain amount of focus. A person slurping while drinking tea creates a different perception for an Asian cultural point of view, as the action is seen to be showing regards to the server of the tea. Whereas for a Western reader, the behaviour would represent the character to be rude towards his environment, and showing disrespect to the server of the tea. The same action would be told by different word choices, and the language would be either supportive or judgemental based on the intended message. In 'Oblomov' by Ivan Alexandrovich Goncharov, Oblomov is a character introduced as a very slowcoach aristocrat, who wakes up late and plans to do things, but his plans never turn into actions. In the beginning of the book, this slowcoach personality of him is criticized by people coming to his house and giving him advices on how to manage his life (Goncharov, 2018). Later in the book, the way he was raised as an aristocrat child is introduced, and the basis for his laziness is justified by people around him, preventing him to take any independent action as a child, which could possibly become 'dangerous' for a child. By time, he adopts that tailormade life for him, and grows his character in that manner. During Oblomov's childhood years, being impassive in daily actions is given as an aristocratic value. The housekeepers condemn the German aristocrats for tying their own shoe and not employing their servants to do their personal work. The conflict of aristocratic virtues is represented also in the plot of the story, and the plot changes from a status- oriented plot to an action-oriented one once the aristocrats change their lifestyles. When the current situation changes and mobility begins in a plot, the plot becomes a state where verbs emerge, and the situations are replaced by the actions. In either case, the plot may create a co-dependency between the elements, as well as may stay alone to carry its own meaning. Therefore, plot 'adds' a positive independent value to a text, and would have a representation of ' $p+$ ' in the formula.

\subsection{Setting}

Settings in texts are designed to create certain emotions and senses by readers. Settings are done by descriptions and portrayals of the given environments. The descriptions and portrayals do not only improve the ability to capture the given environment, but they also create an emotional connection by giving details that the reader can relate to their emotions and thoughts. A purple lavender garden would bring scenery, as well as the smell of lavenders in mind. Compared to the other elements of the textual analysis, the setting is usually the least complicated in terms of understanding and analysing its details, as it directly shapes images in the reader's mind. However, the questions 'why' and 'how' the setting is used in order to shape the main idea may not be as simple as reaching the senses of the readers. Creating a setting would have its details as unique as fingerprints from one text to another. However, its relationship with the main idea can only be observed by its own change: A descriptive idea can only exist and have meaning by its equivalents in concept. A purple lavender garden has an effect on the main idea, once it is understood that it is not a pink rose garden. Therefore, the effect of setting on the main idea can only be given by excluding setting from the other elements, and comparing it with its equivalents to see the descriptive difference it creates. 
In order to observe a real effect in main idea by the setting, the other textual analysis elements should be kept constant. This means the time, the plot and the character effect on the main idea is kept the same, and only the setting is changed. However, the value of the setting cannot be deduced by replacing purple lavender with a pink one, but rather with roses of any colour, in order to get into the 'logic' of the details given. It is not the time, plot, and character kept exactly the same, but it is rather their 'effect' on the main idea being kept the same, in order to observe the difference that the setting creates. Therefore; the value that the time adds to a text is kept the same, the plot line provides the same circumstances, the same character is used, and the setting differs. A fixed value coming from the ' $t+p+c$ ', and any difference added to its main idea given will purely show the value that its setting provides to the text.

The deduction of a setting begins with reaching the same conclusion by using similarly shaped textual elements. However, there would be no effect on the main idea in the end, and that would be useless for the deduction analysis. The intertextual relations in post-modern writings specifically helps to obtain an image when a specific character with her own authentic details are used to represent the shift from one environment to other: In Murathan Mungan's 'A Woman Named Hedda Gabler' story, Mungan reshapes Henrick Ibsen's Hedda Gabler character from 'Hedda Gabler' (Ibsen, 2011), and designs a new world for her in $20^{\text {th }}$ century's Istanbul (Mungan, 2012). Mungan removes the burdens that used to keep Hedda Gabler stuck in the first story, which consisted mainly of her social dependencies. The character then lives in a different time zone in a different city, with different people and expectations around her. The change in the environment does not bring any change to the character's inner self, and Hedda Gabler continues to have her personality clash on whom she is supposed to be. The moment she feels weak again, she holds her father's guns. The article 'Irresistible Inferiority of Being a Woman' compares the two Hedda Gabler, and finds out the direct effects of the change of environment:

Contrary to the previous Hedda's predicament, Hedda in the $21^{\text {st }}$ century, despite the oddness of living at the forefront and the changing circumstances, appears to the reader with the personality traits of the old Hedda: there is a desire to own and to have attention... Love is a space for Hedda Gabler to fill: "He was well aware that no pishov collection could fill that big void in her life... In our economic, social or intellectual exchanges, we always needed men, masculinity and masculinity. Victory was at the end of the barrel. That's why nobody should know her father in life; Hedda Gabler thought (Mungan, 2012, p. 94)" (Karakuş, 2014, p. 20).

Here, the main idea is kept the same in both of the stories, and changing the setting has added a different dimension to the book that now, the reader can observe what would happen differently, and what would remain the same as a result of changing the environment. If a change in the setting can create an additional value in the main idea itself, this supports the setting having its independent value in texts. Moreover, as previously mentioned, a detailed setting with no further text pillar can create a very basic theme itself, which may lead to the main idea, just like creating a message inside a painting by providing sensual and emotional pieces by words. Therefore, setting is taken to be an independent element in the formula, which adds value by itself to the texts, and would be shown as ' $s+$ '.

\subsection{Characters}

Differing from the other pillars, characters cannot independently serve to the main idea. In order for any subject to be a character, it needs to have an 'identity', that is either provided by external elements as the time being and the setting around, or their role in the plot related with other characters of the story. Therefore, logic to be constituted for characters would be based on any of the other 3 pillars, and one can observe the difference each pillar creates on the character to affect the main idea.

Considering time as the determining pillar on characters, there would be 3 time categories to analyse: Pre-modern, modern, and postmodern. In pre-modern literature, the main characters carry a supreme virtue from omnipotent powers. These powers can be related to powerful natural facts or figures, or supernatural powers controlling and interacting with the physical world. 'The Epic of Gilgamesh' as the first known book of literature begins with Gilgamesh being big and fierce-looking character that goes against the law of nature, fights against forests, and wants to challenge death and gods (George, 2003). Later on, in Greek literature, gods interfere with human life directly. In 'The Iliad', gods choose sides between two societies, and try to challenge each other in different ways to protect certain heroes in the story (Silk, 2004). Inside this supreme world of early literature, the characters are expected to behave in certain ways, or otherwise, they are expected to be punished for not acting in that certain manners. In other words, the belief of a supreme power leads to an expectation for a supreme justice to prevent any evil to exist in given societies, which is also referred as 'Deux ExMachina'. Hence, in early literary pieces, the characters represent powers and specific virtues that fight against the 'evils' of the universe in different forms. 
Until the modern era, same connotations are given to kings, heroes, and noble people in society. The powers to be shown, and the heroic acts to be applauded have been shaped by different societies and times in different virtues. The primitive societies were under the attack of wild life, and Gilgamesh was represented to be a fighter against 'forest', which was considered to be an evil and source of danger for the society of its time. Having social life has required new social skills and new virtues; and the survival did not only depend on power, but also having values that would provide continuation of the societies. For Iliad, the society had different values and more complicated 'evils': An evil for one society could be a saver for the other.

Modern literature characters faced an era where the physical and external powers have left their fundamental values to more internal and spiritual ones. In 'Macbeth' by William Shakespeare, Macbeth murders the king to take his throne. He becomes the most powerful man in his society, yet he loses his mental abilities, and in the end, the divine justice takes the throne from him to its real heir. The supreme powers of gods or God-related figures become more of normal human creatures who carry divine virtues. Especially for Western literature, it can also be related to the shift of Protestant values and change of power in social strata. The supreme values start being reachable even by normal people in societies. This creates overloading levels of expectations in life for standard people: Cinderella becomes a real princess, and farmers find magic beans that make them rich one night. Moreover, the changing values create chaos and cause characters to question life even further. 'Madame Bovary' by Gustavo Flaubert is one of the most powerful examples where the main character imagines a supreme goodness in marriage, and dreams of her 'supreme' happiness. Once marriage cannot fulfil her expectations, she starts questioning that 'divine' virtue, and checks for other men to find the 'real love' that would solve all the problems in life and would bring ultimate happiness.

In post-modern literature, the divine supremacy is lowered down to the simplest daily life by 'magic realism'. As one of the core books to be analysed in this content, ' 100 Years of Solitude' by Gabriel Garcia Marquez, the characters have absurd abilities and lives that creates constant confusion between the truth and the imagination many times:

His head was filled with a lot of horror. They taught him to be afraid of women from the streets that will suck their blood, women from the house that give birth to pig-tailed children, cockfights that bring death to people and survivors from life-long pain, unknown adventures that lead to twenty-year wars with a touch, in short, from anything that God's infinite goodness had created and Satan mislead (Marquez, 2008, p. 317).

Here in this novel of Marquez, the supremacy and the supernatural powers of pre-modern stories are re-created in a modern society, and the absurdity of pre-modern stories are given in a plain ground. The shift of the supremacy towards simplicity and normal in literature by time is therefore shown to affect the characters directly.

Considering the plot as the influencing pillar on the characters, it affects character and the way to perceive her, however, a direct effect that could possibly create a direct dependency is not a certain truth. The postmodern literature texts use non-linear plot lines, however, the characters do not necessarily carry the same trend, and they may be chosen to be very stable and not changing, even if the plot changes its behavioural path, characters don't necessarily follow what their 'faith' brings to them or how fast or slow the things around them are shaped. Similarly, for setting, the change in the setting does not necessarily affect the character or its relation to the main idea. In Hedda Gabler example given before, the change in the setting 'adds up' a new value to the text, but it does not change the value added by the character: Hedda still asks for the same things in life, and still brings the same weaknesses and reacts the same in the same weakness situations. Therefore, the character pillar is independent from plot and setting, but dependent to time. Therefore, character is represented as ' $+(t a . c)$ ' where 'ta' represents the partial scope that the time creates difference on characters, and ' $c$ ' represents the character effect on the main idea.

\section{Conclusion and Discussion}

From the given constructivist analysis, done by a realistic approach on text pillars to create a formula for mentors in language classes; 3 elements were found to be independent, whereas 1 is found to be relatively a dependent element. Together, the elements add up to create the main idea. Time creates an independent value, and it is represented as ' $t+$ ' in the formula. Plot shapes a path between the text pillars and the main idea, and it can create a meaning to serve individually, shown by ' $p+$ '. Setting forms a basis for background concepts where senses work to serve to the main idea independently, shown as ' $s+$ '. For the character, it is implied as impossible to judge the pillar in the text without knowing the time zone. Therefore, character is considered to be a time- dependent pillar, and represented as ' $(t a) c$ ' ' where ' $t a$ ' is a certain volume that is connected directly to the use of characters. In conclusion, the formula becomes 


$$
\text { ' } t+p+s+(t a) c=m \text { ' }
$$

where ' $m$ ' represents the main idea to be reached.

The textual analysis requires a wide background for the readers to observe not only the elements of the texts, but also the connection between them, and the values each textual element provides to the text (as whole) to create its meaning. For years, comprehension activities based on texts have been done by using direct teaching methods, where lecturers were in charge to reach the main idea, and show the ways to find the details to support it by using sub-text questions. However, textual analysis proposes to create more personal space for the learners, and expect them not to memorize, but to learn concepts and to shape values based on their own perception of the world. In other words, not only comprehension but also analysis and evaluation activities are done in constructivist learning environments. The limitless options of combinations to create meanings and information from the given texts to widen learner perspectives requires high levels of coordination and experience, which leads to a need for a prepared sample to mentor the instructors before they mentor students. Providing an open space for different perspectives and creativity may also lead partial losses or misinterpretations of the main idea. McPhail criticizes the constructivist based educational curricula by emphasizing them "lacking criticism and clarity concerning constructivism's meanings and application which results in both conformity and confusion within the discursive site" (McPhail, 2016, p. 295). The constructivist approach on teaching brings ideas from various disciplines, and according to Bernstein, as well as it looks ideological at first, it focuses on following a globalization trend with no pedagogical concern (Bernstein, 2000).

Cole (1990), however, supports the constructivist teaching method as it puts forward individual development in learning as well as providing an environment to combine the new information with one's own context to create a complex knowledge structure. In the end, more information is internalized by learners (Cole, 1990). The educational focus in the constructivist curricula are not on how much given information is learnt, but rather how well it is proceeded to create difference, and as personal as it gets, it becomes harder to measure how well the topic is learnt by students. Therefore, the criteria to evaluate success are different, and the old methods cannot be shown as they teach more. Kaufman (2004) advocates a step further adding that the readers' construction of the texts before reading is also shaped by the context they visualize for gathering new information. By gaining a broader understanding with constructivist curricula, the contexts to visualize for relevant learning topics may also be increased as they may provide broader contexts. Kaufman also emphasizes the need for interdisciplinary preparation of mentors by peering in classes to enhance the language-learning process as well as widening student perspectives on the same subject (Kaufman, 2004). In order to provide a wide-learning environment, mentors should provide different ways of analysing texts, and this can only be possible by mastering relevant subjects. Brooks (2002) sees the interdisciplinary teaching approach to be a real challenge for systems that change their teacher-oriented teaching methods to mentoring learner-oriented methods, while McCarty and Schwandt argues that not all the mentors are yet capable to do the mentoring process with constructivist values (McCarty \& Schwandt, 2000, p. 42; cited in McPhail, 2016, p. 304).

As Wang and Peyvandi (2018) explain, constructivist teaching is a relatively new method, which may also require the lecturers to forget what they experienced from their teachers before. The mentors do not only provide relevant information, but they also become facilitators, models, coaches, and scaffolders in their classes (Tam, 2000; Jonassen, 1991; cited in Wang \& Peyvandi, 2018). As well as it is new to learners, the system might be new for language teachers, and this article provided an alternative path to follow the constructivist mentoring system by formulating the textual elements being used, so to create a path for the learner and the mentor to follow, and also leaving space for them to contribute uniquely. The new curricula have different objectives to evaluate success of learners, and yet, any teaching approach should be shaped accordingly, while the objectives are also given in clear concepts to accomplish those objectives.

\section{References}

Bernstein, B. (2000). Pedagogy, symbolic control and identity: Theory, Research, Critique (Revised Edition) New York.

Bronte, C. (1993). Villette. Wordsworth Editions, Wordsworth Classics.

Brooks, J. G. (2002). Schooling for Life: Reclaiming the Essence of Learning. Alexandria, VA: Association for Supervision and Curriculum Development (ASCD).

Caelli, K., Ray, L., \& Mill, J. (2003). "Clear as mud”: Toward greater clarity in generic qualitative research. International Journal of Qualitative Methods, 2(2), 1-24. https://doi.org/10.1177/160940690300200201

Cole, M. (1990). Cognitive Development and Formal Schooling: The Evidence from Cross-Cultural Research. In 
L. Moll (Ed.), Vygotsky and Education: Instructional Implications and Applications of Sociohistorical Psychology. New York: Cambridge University Press. https://doi.org/10.1017/CBO9781139173674.005

Dostoyevsky, F. (2012). Idiot (Ergin Altay, Trans.) Istanbul: Türkiye İş Bankası Publishing.

Flora, J. M. (1989). Hemingway's Theory of the Short Story: A Study of the Short Fiction. Boston: Twayne Publishers.

Fürsich, E. (2018). Textual Analysis and Communication. Oxford University Press. https://doi.org/10.1093/obo/9780199756841-0216

George, A. (2003). The Epic of Gilgamesh. London: Penguin Books.

Goncharov, I. A. (2018). Oblomov (Ergin Altay, Trans.). Istanbul: İletişim Publishing

Holloway, I., \& Todres, L. (2003). The status of method: Flexibility, consistency and coherence. Qualitative Research, 3(3), 345-357. https://doi.org/10.1177/1468794103033004

Ibsen, H. (2011). Hedda Gabler (Yilmaz Öğüt Trans.). Istanbul: Mitos-Boyut Theatre Publishing.

Johnson, M., Long, T., \& White, A. (2001). Arguments for "British Pluralism" in qualitative health research. Journal of Advanced Nursing, 33(2), 243-249. https://doi.org/10.1046/j.1365-2648.2001.01659.x

Kahlke, M. (2014). Generic Qualitative Approaches: Pitfalls and Benefits of Methodological Mixology. International Journal of Qualitative Methods, 13, 37-52. https://doi.org/10.1177/160940691401300119

Karakus, G. (2014). Kadın Olmanın Dayanılmaz Hafifliği [Irresistible Impulse of Frivolousness in Women]. IB Extended Essay. Erzurum.

Kaufman, D. (2004). Constructivist Issues in Language Learning and Teaching. Annual Review of Applied Linguistics: Cambridge (Vol. 24, pp. 303-319). https://doi.org/10.1017/S0267190504000121

Kretchmar, J. (2019). Constructivism. Salem Press Encyclopedia.

Landmasser, C. (2015). Geschichte und Eschatologie; Rudolf Bultmanns Gifford Lectures aus dem Jahr 1955 [Rudolf Buttmann's Lectures]. Ephemerides Theologicae Lovanienses, 91, 461-479.

Marquez, G. G. (2003). Chronicle of a Death Foretold. United States of America: Vintage Publication.

Marquez, G. G. (2008). 100 Years of Solitude (Seçkin Selvi Trans.). İstanbul: Can Publication.

McKee, A. (2003). Textual Analysis: A Beginner's Guide. London: SAGE Publications Ltd. https://doi.org/10.4135/9780857020017

McPhail, G. (2016). The fault lines of recontextualisation: The limits of constructivism in education. British Educational Research Journal, 42(2), 294-313. https://doi.org/10.1002/berj.3199

MEB. (2019). Türkçe Öğretim Programı [Turkish Teaching Curriculum]. Ankara.

Merriam, S. B. (1998). Qualitative research and case study applications in education. San Francisco: Jossey-Bass.

Merriam, S. B. (2009). Qualitative research: A guide to design and implementation. San Francisco, CA: Jossey-Bass.

Morse, J. M. (1989). Qualitative nursing research: A free-for-all? In J. M. Morse (Ed.), Qualitative nursing research (pp. 3-14). Rockville, MD: Aspen Publishers. https://doi.org/10.4135/9781483349015.n2

Mungan, M. (2012). Kırk oda. Istanbul: Metis Publishing.

Richards, L., \& Morse, J. M. (2007). Readme first for a user's guide to qualitative methods. Thousand Oaks, CA: Sage.

Salman, B., \& Aydın, İ. (2018). Yapılandırmacı Yaklaşıma Göre Dil Bilgisi Öğretimine Yönelik Öğretmen Görüşleri [Teachers' View on the Subject of Grammar Education According to Constructivism]. Turkish Studies, 13(27), 1265-1284. https://doi.org/10.7827/TurkishStudies.14304

Shakespeare, W. (2012). Macbeth (Sabahattin Eyüboğlu Trans.). İstanbul: Türkiye İş Bankası Publishing.

Silk, M. S. (2004). Homer, The Iliad. Cambridge: Cambridge University Press. https://doi.org/10.1017/CBO9780511808197

Smith, J., Bekker, H., \& Cheater, F. (2011). Theoretical versus pragmatic design in qualitative research. Nurse Researcher, 18(2), 39-51. https://doi.org/10.7748/nr2011.01.18.2.39.c8283 
Ünveren, D. (2016). Söylem Çözümleme Yönteminin Türk Dili ve Edebiyatı Öğretiminde Kazandırılması Hedeflenen Becerilere Etkisi [The Effect of Discourse Analysis Method Use for The Aimed Skills in Turkish Language and Literature Teaching]. (PhD thesis, Erzurum: Ataturk University Language Teaching Institution Turkish Language Teaching Faculty).

Wang, J., \& Peyvandi, A. (2018). Objectivism versus Constructivism in Global Business Education: An Empirical Study. California State University, Fresno. International Journal of Education Research, 13(1).

Worthington, M. (2010). Differences between phenomenological research and a basic qualitative research design. London: Capella University. Retrieved from http://a1149861.sites.myregisteredsite.com/DifferencesBetweenPhenomenologicalResearchAndBasicQualit ativeResearchDesign.pdf

Yılmaz, K., \& Şeker, M. (2011). Ilköğretim Öğrencilerinin Sosyal Bilgilere Karşı Tutumlarının İncelenmesi [Examining the Attitudes of Primary School Students Towards Social Sciences]. Journal of Istanbul Aydin University, 1(3), 34-50.

\section{Copyrights}

Copyright for this article is retained by the author(s), with first publication rights granted to the journal.

This is an open-access article distributed under the terms and conditions of the Creative Commons Attribution license (http://creativecommons.org/licenses/by/4.0/). 